\title{
ПОСЕЛЕНСЬКІ ГІДРОЕКОСИСТЕМИ ЧЕРКАСЬКОЇ ОБЛАСТІ ТА ЇХНІЙ ЕКОЛОГІЧНИЙ СТАН
}

\author{
Кисельов Ю. О., Шутак К. В.
}

\section{ВСТУП}

Істотне погіршення екологічної ситуації є однією з властивих ознак сучасного етапу розвитку цивілізації. Поряд з іншими компонентами ландшафтної оболонки Землі суттєвих антропогенних змін зазнає гідросфера - як на планетарному рівні (зокрема, через забруднення вод Світового океану нафтопродуктами й іншими полютантами), так і на регіональному й локальному внаслідок надходження до річок, озер й інших водотоків і водойм, а також підземних вод різноманітних токсикантів. Безперервна участь води у світовому кругообігу речовини викликає небезпеку забруднення через водні об'єкти інших компонентів ландшафтів.

Глобальне погіршення екологічного стану водного середовища цілковито стосується України, якій за часів перебування у складі СРСР був притаманний індустріально-аграрний напрям розвитку 3 переважанням важкої промисловості у структурі господарського комплексу. Одним із найістотніших негативних наслідків нераціонально здійснюваної індустріалізації стало забруднення різноманітними виробничими відходами річок та інших гідрооб'єктів. Функціонування вугільних шахт і великих металургійних підприємств спричинило значне забруднення правих приток Сіверського Донця, річок Приазов'я, деяких лівих приток Дніпра. У результаті Чорнобильської катастрофи зазнали радіоактивного забруднення Прип'ять і Київське водосховище. Зрештою саме спорудження каскаду водосховищ (а отже, i розвиток гідроенергетики на Дніпрі як такої) в умовах переважно рівнинного характеру долини було екологічно необгрунтованим.

Черкаська область, якій хоч і властивий сприятливий стан навколишнього середовища порівняно 3 такими областями, як Дніпропетровська, Донецька, Луганська, все ж має деякі екологічні проблеми, викликані забрудненням водних об'єктів. Оскільки Черкащина характеризується аграрною спеціалізацією господарства, такі проблеми мають досить виражену територіальну прив'язаність до спорадично розташованих міст, іноді інших категорій населених пунктів. Через те було б доцільно виділити дослідження гідроекологічних проблем населених місць із загального контексту вивчення екологічного стану 
водних об’єктів. На нашу думку, цим питанням мала б займатися особлива наукова дисципліна - поселенська гідроекологія.

Об'єктом поселенської гідроекології є поселенські гідроекосистеми, під якими розуміють поєднання всіх водних об'єктів (природних i штучних, стічних і безстічних, поверхневих і підземних), гідротехнічних споруд і систем водопостачання в межах населеного пункту та його околиць. Предметом поселенської гідроекології $\epsilon$ закономірності формування, структура й функціонування поселенських гідроекосистем й управління ними.

Поселенські гідроекосистеми є досить різноманітними, що пов'язано 3 відмінностями джерел водопостачання, розмірністю населених пунктів тощо. Зокрема, сільській місцевості найбільш притаманне децентралізоване водопостачання; міста, як правило, забезпечуються водою 3 річок або водосховищ. Великі міста можуть мати кілька різних джерел водопостачання. Тому доречно виокремлювати гідроекосистеми сіл, селищ, малих, середніх, великих і найбільших міст (міські поселенські гідроекосистеми ми називаємо також урбогідроекосистемами ${ }^{1}$.

Будь-якій поселенській гідроекосистемі, незалежно від рангу й розміру населеного пункту, властиві цілісність і завершеність, спричинені внутрішньою єдністю самих поселень i водночас дискретністю поселенських систем.

Можливість виконання водними об'єктами функцій джерел водопостачання суттєво залежить від їхнього екологічного стану, тому вивчення гідрологічних, гідрохімічних і гідроекологічних характеристик природних вод перебуває в тісному зв'язку з дослідженням просторових відносин між геооб'єктами (наприклад, річкою й містом), аналізом впливу різноманітних антропогенних факторів на формування загальної екологічної ситуації, оцінкою природних (зокрема, геоморфологічних) передумов погіршення екологічного стану водного середовища тощо.

\section{1. Структура поселенських гідроекосистем Черкаської області та їх групування}

Як ми зауважили вище, населені пункти (разом із територіями їхнього впливу) з усіма водотоками й водоймами, розташованими в них, та підземними водами, які мають значення для водопостачання, утворюють особливі просторові об'єкти - поселенські гідроекосистеми. Останні в себе включають: 1) усі природні поверхневі й підземні води, наявні на території впливу населеного пункту; 2) гідротехнічні споруди; 3) водопровідні комунікації; 4) населення; 5) власне територію поселенської гідроекосистеми. Наведені компоненти варто об’єднати у два

\footnotetext{
${ }^{1}$ Кисельов Ю. О., Шутак К. В. До проблеми формування наукових засад урбогідроекології. Молодий вчений. № 7 (71). 2019. С. 10-13.
} 
підкомпоненти - природний, представлений територією й водними об'єктами, та антропогенний, до якого належать населення, гідротехнічні споруди й комунікації. Своєю чергою в рамках антропогенного підкомпоненту можна виділити такі структурні блоки, як антропічний (представлений самою людиною) й технічний, який містить різноманітні гідротехнічні об'єкти.

Вищезазначені різнорангові складники поселенської гідроекосистеми характеризуються наявністю горизонтальних і вертикальних зв'язків, які й утворюють іï структуру. Це, зокрема, функціональні зв'язки між компонентами, що забезпечують єдність системи, а також зв'язки між підкомпонентами, компонентами й поселенською гідроекосистемою в цілому, що визначають іiі ієрархічну будову.

Основними проявами функціонування поселенської гідроекосистеми $\epsilon$, на нашу думку, такі: 1) участь усієї наявної на іiі території води в процесі світового кругообігу; 2) зарегульованість водотоків внаслідок побудови на них гідротехнічних споруд - дамб, загат та інших; 3) залучення значних мас води до систем водопостачання; 4) зміни напрямів неруслових потоків води на урбанізованих територіях внаслідок штучного перетворення рельєфу; 5) більша піддатливість води до різних видів забруднень в умовах міських і приміських територій. 3 вищезгаданих пунктів тільки перший віддзеркалює природний порядок речей, що не залежить від волі людини та існував ще до ії виникнення. Інші засвідчують ті чи інші форми антропогенного впливу - як безпосереднього й цілеспрямованого (пов'язаного з функціонуванням гідротехнічних споруд і систем водопостачання), так і опосередкованого та несвідомого (зокрема, через зміни рельєфу поверхні, що являє собою арену переміщення вод; забруднення водних об'єктів скидами промислових підприємств і транспорту тощо). Отже, безсумнівно, що людина та її діяльність мають першорядне значення для функціонування поселенських гідроекосистем.

Серед поселенських гідроекосистем Черкаської області найбільш розгалуженими та складноорганізованими $є$ гідроекосистеми Черкас, Умані, Сміли, Золотоноші, Ватутіного, Канева, тобто міст обласного підпорядкування. До природного підкомпоненту згаданих поселенських гідроекосистем належать води річок, водосховищ, ставків, підземні води.

У Черкасах гідрологічні характеристики Дніпра істотно відрізняються від тих, які були йому притаманні у природному стані. Кременчуцьке водосховище, пов'язане 3 однойменною гідроелектростанцією, являє собою водоймище, що поєднує в собі риси річки й озера. Через функціонування електростанції в ньому зазнали суттєвих змін річковий стік і водний режим Дніпра, умови життя прісноводних організмів, хімічний склад води. 
До поселенської гідроекосистеми Черкас входять частина акваторії Кременчуцького водосховища, підземні води, які на території міста й поблизу нього виходять на поверхню, а також системи водопостачання й водовідведення та власне міська територія й населення. Зв'язки компонентів гідроекосистеми зумовлені, 3 одного боку, рельєфом місцевості, який спрямовує лінійні та нелінійні потоки води в напрямку Дніпра, поглинутого в останні 60 років Кременчуцьким водосховищем, та, з іншого боку, гідравлічними властивостями гідротехнічних споруд, що безпосередньо забезпечують місто водою.

Гідрооб'єкти Умані так само характеризуються значним антропогенним перетворенням. У межах міста протікають дві річки - Уманка (притока Ятрані, що належить басейнові Південного Бугу) та Кам'янка (притока Уманки). В обох річках стік зарегульований штучними водоймами - Осташівським ставом і системою ставків у Національному дендропарку «Софіївка» та на території, що його оточує.

До поселенської гідроекосистеми Умані належать не лише згадані вище річки, ставки й підземні води, але також гідротехнічні споруди, система водопостачання й водовідведення, населення та міська територія. Досить пересічений рельєф іiі поверхні визначає напрямки переміщення по ній дощових і талих вод.

Золотоноша розташована на лівобережній частині Черкаської області. Хоча це місто й не досягає Кременчуцького водосховища, все ж воно чинить істотний вплив на урбогідроекосистему. Осьовою у складі останньої є річка Золотоношка - ліва притока Дніпра. Загалом до поселенської гідроекосистеми Золотоноші належать прилегла до неї частина Кременчуцького водосховища, річка Золотоношка, гідротехнічні споруди, підземні води в межах міста й прилеглої території, власне територія та населення.

Канів розташований на правому березі Дніпра. Істотне значення для міста має також річка Рось, яка хоч і тече поза його межами, але суттєво впливає на міську гідроекосистему. Крім згаданих вище річок, до канівської урбогідроекосистеми належать наявні в межах міста і його околиць підземні води, гідротехнічні споруди, населення й територія.

Меншим населеним пунктам - малим містам, селищам i селам властиві простіші за структурною організацією поселенські гідроекосистеми. Найчастіше до їхнього складу входить лише одна річка разом із підземними водами, гідротехнічними спорудами, населенням i територією. До деяких сільських поселенських гідроекосистем належать лише територія, населення й децентралізовані джерела водопостачання.

Загалом на земній поверхні сформувалася величезна кількість поселенських гідроекосистем. Згідно з використовуваним у рамках системного підходу правилом спрощення немає потреби проводити 
дослідження кожної з них окремо. Тому необхідним є групування поселенських гідроекосистем за певними ознаками ${ }^{2}$.

Можливе застосування двох підходів для здійснення такого групування. Зокрема, це може бути басейновий підхід, відповідно до якого поселенські гідроекосистеми утворюють групи за критерієм належності до басейну великої або середньої річки. Позитивною рисою цього підходу $\epsilon$ врахування функціональних залежностей між поселенськими гідроекосистемами, розміщеними в межах долини однієї річки. Наприклад, до однієї такої групи, згідно із засадами басейнового підходу, належать поселенські гідроекосистеми деяких сіл південної частини Уманського району, через які тече річка Ятрань (рис. 1). Таке сполучення поселенських гідроекосистем варто досліджувати разом як певну єдність.

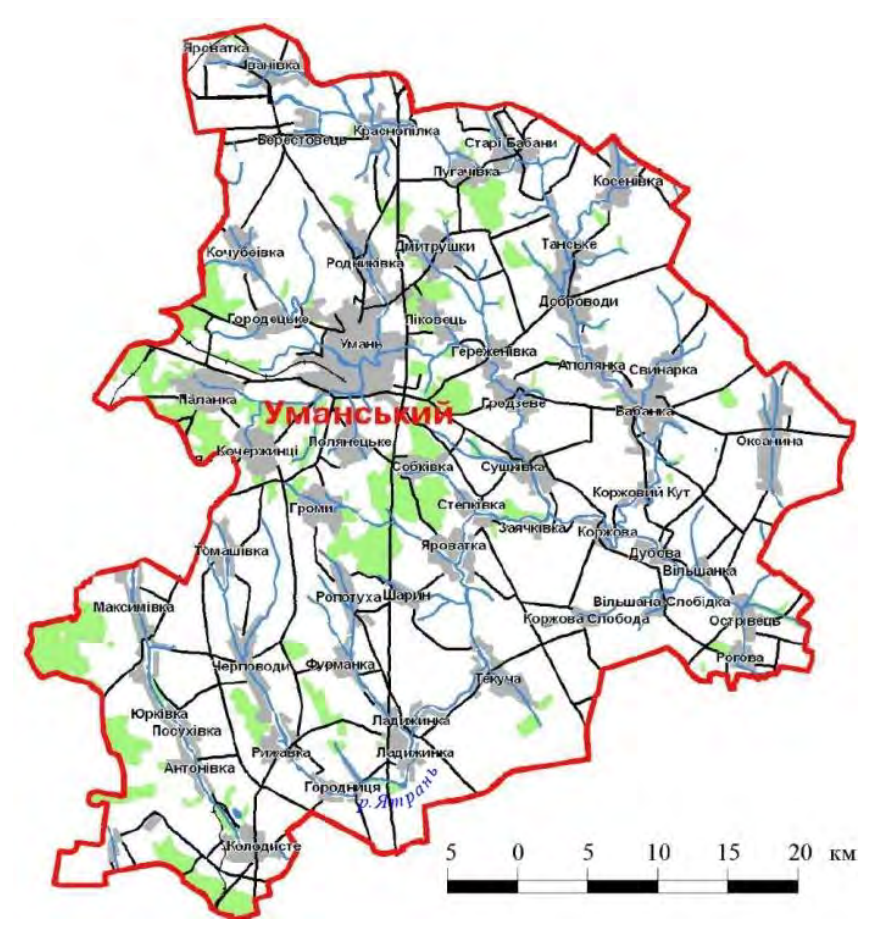

Рис. 1. Картосхема Уманського району

Так, основою поселенської гідроекосистеми Умані є річки Уманка та Кам'янка (разом зі штучно створеними на них ставками), які течуть також через інші населені пункти, формуючи разом із відповідними поселенськими гідроекосистемами певну групу.

У разі застосування басейнового підходу ми виділяємо такі найбільші групи поселенських гідроекосистем Черкащини з осьовим значенням великої або середньої (не менше ніж 100 км завдовжки) річки: системи

\footnotetext{
${ }^{2}$ Кисельов Ю. О., Шутак К. В. Основні підходи до групування поселенських гідроекосистем Черкаської області. SWorld Journal. Травень 2020. Вип. 4. Ч. 1. С. 98-101.
} 
Дніпра, Гірського Тікича, Тясмина, Гнилого Тікича, Ятрані, Росі, Супоя та Великої Висі (рис. 2). Кожна така група має менші групи, роль осей у яких належить малим річкам. Ці малі групи безпосередньо складаються з елементарних (найчастіше сільських) поселенських гідроекосистем.

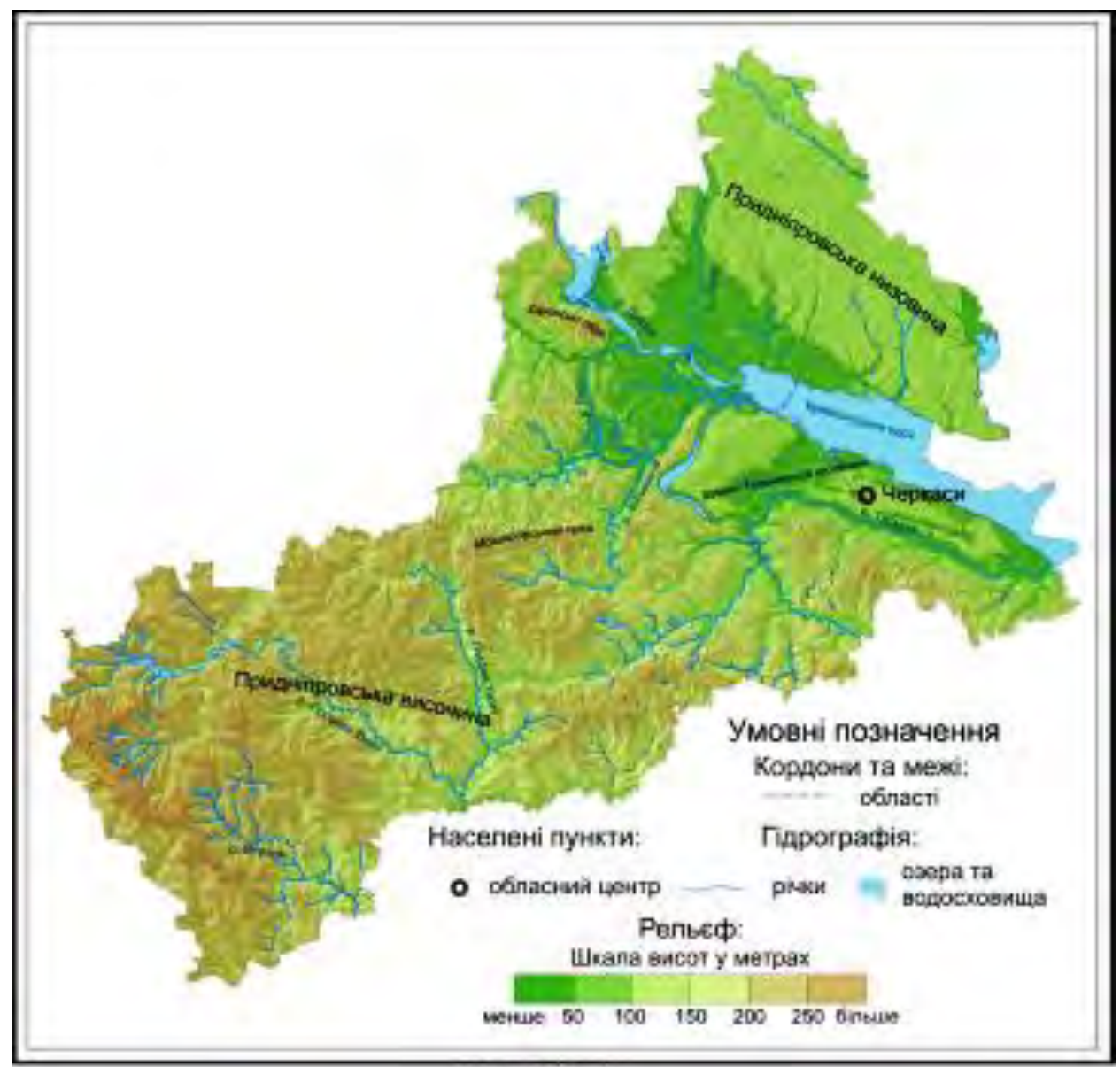

Рис. 2. Картосхема Черкаської області

Альтернативний підхід полягає в об’єднанні переважно сільських, невеликих за площею й досить простих за структурою, поселенських гідроекосистем навколо міської (урбогідроекосистеми) або селищної, що охоплює велику територію та є складно організованою. Перевагою цього підходу $\epsilon$ наголос на населеному пункті як одному 3 основних компонентів поселенських гідроекосистем. Наприклад, на території Уманського району ми пропонуємо виокремлювати уманську, бабанську й ладижинську групи поселенських гідроекосистем з інтегрованими до них численними сільськими (елементарними) поселенськими гідроекосистемами (рис. 1).

Використовуючи такий підхід, названий нами екістичним (екістика наука про поселення), ми виділяємо групи поселенських гідроекосистем навколо міських населених пунктів (міст і селищ міського типу), а також тих сіл, що в минулому були районними центрами. Ідеться про 356 
40 населених пунктів Черкаської області. Структурна та функціональна єдність поселенських гідроекосистем досягається завдяки їхній відповідності системам розселення. Однією з важливих рис останніх часто $є$ інтегрованість систем водопостачання.

Зокрема, 3 Уманню агломераційними зв'язками поєднані села Городецьке, Дмитрушки, Піківець, Родниківка тощо. Тому й поселенські гідроекосистеми згаданих сіл варто розглядати в контексті уманської урбогідроекосистеми. Незважаючи на те що не всі вищезгадані села стоять над річками Уманка та Кам'янка, як місто Умань, ці річки є для них найближчими. Саме вони мають важливе значення для водопостачання якщо не самих сільських поселень, то принаймні зон їхнього впливу (сільськогосподарських угідь тощо). Проте головним фактором, який об'єднує сільські поселенські гідроекосистеми навколо міської, є екологічний: розташовані в межах міста промислові об'єкти забруднюють водне середовище, і не лише в самому місті, а й у навколишніх селах. Водночас належність місцевих водотоків до того чи іншого річкового басейну значення не має.

Особливу категорію становлять населені пункти, де немає поверхневих водотоків, а за джерела водопостачання правлять виключно підземні води. За таких умов утворюються автономні гідроекосистеми, які ні структурно, ні функціонально не пов'язані з басейновими групами поселенських гідроекосистем. Прикладом може бути село Ропотуха Уманського району, яке одержує воду з криниць і свердловини.

Схарактеризований вище басейновий підхід до групування поселенських гідроекосистем можна вважати природничо-географічним, позаяк його основою $є$ земні реалії, що склалися ще до появи людини на Землі, - природні водні об’єкти. Водночас екістичний підхід є соціальноекологічним, тому що за його застосування наголос робиться на населених пунктах i їхніх мешканцях, а також деяких екологічних наслідках господарської діяльності. Об'єднує обидва підходи те, що вони, незалежно від змісту конкретних об'єктів, передбачають здійснення аналізу просторових відносин між ними та закономірностей їхнього функціонування. Через те в різнобічному дослідженні поселенських гідроекосистем ми вбачаємо яскраво виражений географічний зміст. Акцентування на екологічних аспектах їх функціонування визначає конструктивно-географічний аспект їх вивчення.

Як басейновий, так і екістичний підходи до групування поселенських гідроекосистем ми визнаємо однаково коректними й такими, що не суперечать один одному, але взаємодоповнюють, даючи змогу з різних позицій досліджувати певні риси функціонування цих систем, характер і ступінь антропогенного впливу на них, а також перспективи оптимізації їхнього екологічного стану. 


\section{2. Антропогенне забруднення поселенських гідроекосистем Черкащини}

Основними показниками екологічного стану поселенських гідроекосистем ми вважаємо об'єми забруднення річок і водоймищ зворотними водами, обсяги скидів й об'єми скидання полютантів і загальні показники забруднення.

За відомчими даними профільних управлінь Черкаської обласної державної адміністрації, кількісні значення скидання зворотних вод у поверхневі водні об'єкти в середньому становлять близько 175-190 млн м Найбільші об'єми зворотних вод спричинені викидами сільськогосподарських підприємств, об'єктів промисловості та житловокомунального господарства. Саме на останні припадає найбільше забруднених стічних вод - 76,1\%. Забруднення водних об'єктів стічними водами найчастіше зумовлено неефективною роботою очисних споруд або відсутністю останніх. Під час здійснення лабораторного контролю за якістю зворотних вод зафіксовано 37 випадків перевищень нормативів гранично допустимого скидання забруднюючих речовин на восьми підприємствах області ${ }^{3}$.

За фондовими матеріалами Черкаської облдержадміністрації, найбільшими забруднювачами природних вод Черкащини $є$ комунальне підприємство «Уманьводоканал», чиї щорічні об’єми скидання зворотних вод становлять близько 2500-2600 тис. м ${ }^{3}$; «Черкаське експлуатаційнолінійне управління автомобільних шляхів» (1300-1700 тис. м $\left.{ }^{3}\right)$; підприємство «ВодГео» в місті Смілі (1100-1300 тис. м³); «Водоканал» міста Золотоноша (700-800 тис. $\left.\mathrm{m}^{3}\right)$; «Водоканал» міста Ватутіне (500-600 тис. м $^{3}$. Варто зауважити, що приріст об'ємів забруднення за роками (2018 р. порівняно з 2016 р.) спостерігається щодо підприємств Черкас, Умані й Ватутіного. У розрізі басейнових груп поселенських гідроекосистем найбільші об'єми забруднень припадають на басейни Дніпра, Ятрані, Тясмина та Гнилого Тікича. Дані про об’єми забруднення зворотними стічними водами гідрооб'єктів за басейновими групами та приріст показників забруднення наведено в табл. 1.

3 наведених даних видно, що найбільші значення забруднення гідрооб'єктів зворотними стічними водами й максимальні величини приросту забруднень притаманні групам поселенських гідроекосистем Дніпра та Ятрані. Ми вбачаємо в цьому закономірність, оскільки, поперше, у басейнах вищезгаданих річок розташовані найбільші міста Черкащини - Черкаси та Умань; по-друге, зазначені річки мають найбільшу на території області кількість приток. У динаміці забруднень у групах поселенських гідроекосистем Гірського й Гнилого Тікичів, Південного Бугу й Росі ми не знаходимо чітко окреслених тенденцій,

\footnotetext{
${ }^{3}$ Екологічний паспорт Черкаської області на 2017 рік. Черкаси, 2018. 261 с.
} 
тому що приріст залишається переважно на рівні, що не перевищує 5-15 тис. м³. Суттєве зменшення обсягів забруднення в межах тясминської басейнової групи поселенських гідроекосистем, зумовлене мінімізацією викидів підприємствами Кам'янки, Чигирина й особливо Сміли, ми пояснюємо процесами деіндустріалізації, притаманними сьогоднішній Україні, вираженими, зокрема, в істотному скороченні обсягів виробництва на промислових підприємствах, особливо на Смілянському машинобудівному заводі.

Таблиця 1

Об'єми та динаміка забруднення водних об'сктів Черкаської області зворотними стічними водами (за басейновими групами поселенських гідроекосистем ${ }^{4}$ )

\begin{tabular}{|c|c|c|c|}
\hline \multirow{2}{*}{$\begin{array}{c}\text { Басейнова група } \\
\text { поселенських } \\
\text { гідроекосистем }\end{array}$} & \multicolumn{2}{|c|}{$\begin{array}{l}\text { Об'єми забруднень за } \\
\text { роками, тис. } \text { м }^{3}\end{array}$} & \multirow{2}{*}{$\begin{array}{c}\text { Приріст у } 2018 \text { p. } \\
\text { порівняно з } 2016 \text { р., } \\
\text { тис. } \text { м }^{3}\end{array}$} \\
\hline & 2016 & 2018 & \\
\hline Дніпро & 2397 & 3454 & 1057 \\
\hline Ятрань & 2538 & 2791 & 253 \\
\hline Тясмин & 1622 & 1270 & -352 \\
\hline Гнилий Тікич & 532 & 599 & 67 \\
\hline Південний Буг & 107 & 117 & 10 \\
\hline Гірський Тікич & 102 & 107 & 5 \\
\hline Рось & 22 & 35 & 13 \\
\hline
\end{tabular}

Співвідношення об'ємів забруднення водних об'єктів у розрізі основних груп поселенських гідроекосистем представлено на рис. 3 .

Розглядаючи 3 погляду екістичного підходу питання забруднення гідрооб'єктів зворотними стічними водами, ми спостерігаємо залежність об'ємів забруднень, передовсім від величини міста, яке є центром групи поселенських гідроекосистем. Винятками є лише співвідношення об'ємів забруднень, зумовлених діяльністю водогосподарських комунальних підприємств Умані й Черкас: гідрооб'єкти уманської урбогідроекосистеми вирізняються майже вдвічі більшою забрудненістю порівняно з черкаською. В інших випадках закономірність повністю підтверджується, оскільки значно більші показники забруднення властиві екістичним групам поселенських гідроекосистем, утвореним навколо міст обласного підпорядкування, зокрема смілянській, золотоніській, ватутінській. За порівняння об'ємів забруднень виявляється, що перші позиції посідають уманська та черкаська групи

4 Шутак К. В. Техногенне забруднення поселенських гідроекосистем Черкаської області. The 11th International scientific and practical conference "Dynamics of the development of world science", July 8-10, 2020. Perfect Publishing, Vancouver, Canada. C. 479-489. 
урбогідроекосистем, за ними йдуть смілянська, золотоніська, ватутінська та інші. Показники, наведені в табл. 2, на нашу думку, є достатньо репрезентативними, навіть попри брак даних про деякі інші екістичні групи поселенських гідроекосистем, у тому числі про звенигородську, катеринопільську, лисянську, маньківську, монастирищенську та інші.

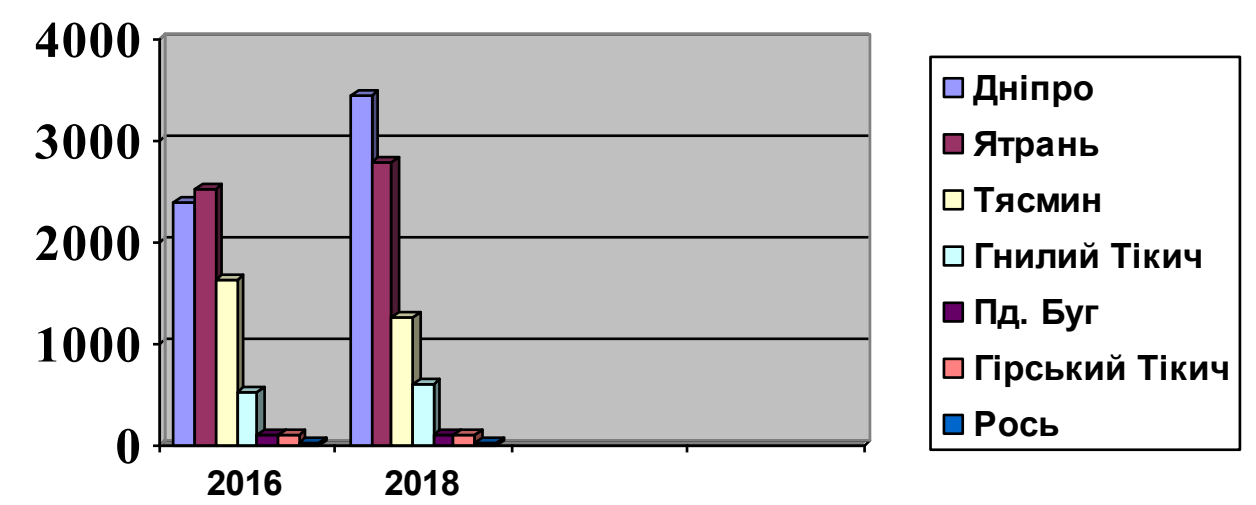

\section{Рис. 3. Співвідношення об'смів забруднень водних об'єктів за основними басейновими групами поселенських гідроекосистем Черкащини, тис. км ${ }^{35}$}

3 таблиці видно, що й у розрізі екістичних груп поселенських гідроекосистем проявляється та ж закономірність, яку ми спостерігали під час аналізу показників забруднень за басейновими групами. Найбільші показники мають уманська, черкаська, смілянська, золотоніська й ватутінська групи, що пов'язано з розміром і статусом згаданих міст, а відтак - кількістю споживачів водних ресурсів i об'ємами води, що проходить через водопровідні споруди.

Найбільші значення приросту об'ємів забруднень властиві головним чином екістичним групам поселенських гідроекосистем західної частини Черкащини (та, крім того, черкаській урбогідроекосистемі), що ми пояснюємо впливом соціально-економічних факторів. Найсуттєвіше забруднення природних вод у межах уманської групи поселенських гідроекосистем ми частково пов'язуємо з тим, що питна вода до Умані надходить із міста Біла Церква, що розташоване у понад 120 км, а водопровідні комунікації споруджено давно, вони тепер є застарілими, а тому нерідко зазнають аварій, що викликають забруднення безпосередньо гідрооб’єктів.

5 Шутак К. В. Техногенне забруднення поселенських гідроекосистем Черкаської області. The 11th International scientific and practical conference "Dynamics of the development of world science", July 8-10, 2020. Perfect Publishing, Vancouver, Canada. 2020. C. 479-489. 
Забруднення водних об'єктів Черкаської області зворотними стічними водами в розрізі найбільших екістичних груп поселенських гідроекосистем ${ }^{6}$

\begin{tabular}{|c|c|c|c|}
\hline \multirow{2}{*}{$\begin{array}{l}\text { Поселенські групи } \\
\text { гідроекосистем }\end{array}$} & \multicolumn{2}{|c|}{$\begin{array}{l}\text { Об'єми забруднень } \\
\text { за роками, тис. }{ }^{3}\end{array}$} & \multirow{2}{*}{$\begin{array}{c}\text { Приріст у } 2018 \text { p. } \\
\text { проти } 2016 \text { p., } \\
\text { muс. } \mathcal{M}^{3}\end{array}$} \\
\hline & 2016 & 2018 & \\
\hline Уманська & 2538 & 2603 & 65 \\
\hline Черкаська & 1541 & 1732 & 191 \\
\hline Смілянська & 1362 & 1116 & -246 \\
\hline Золотоніська & 788 & 763 & -25 \\
\hline Ватутінська & 532 & 599 & 67 \\
\hline Христинівська & 107 & 117 & 10 \\
\hline Чигиринська & 113 & 110 & -3 \\
\hline Тальнівська & 91 & 96 & 5 \\
\hline Чорнобаївська & 75 & 78 & 3 \\
\hline Кам'янська & 78 & 44 & -34 \\
\hline $\begin{array}{l}\text { Корсунь- } \\
\text { Шевченківська }\end{array}$ & 22 & 35 & 13 \\
\hline Жашківська & 8 & 9 & 1 \\
\hline
\end{tabular}

Найменші (в тому числі навіть від'ємні) показники приросту об'ємів забруднень характерні для південно-східних районів Черкаської області (Золотоніського, Кам'янського, Смілянського, Чигиринського, Чорнобаївського), що зумовлено фактичною відсутністю або зупиненням роботи деяких водомістких промислових об'єктів із водомістким виробництвом.

Загалом показники приросту, що дорівнюють від (-)50 до 50 тис. м³ не дають достатнього уявлення про певну тенденцію, тому ми їх вважаємо незначними, а відтак доречним буде стверджувати про практичну відсутність приросту забруднення в таких екістичних групах поселенських гідроекосистем, як жашківська, золотоніська, корсуньшевченківська, тальнівська, христинівська, чигиринська, чорнобаївська.

Показники обсягів скидів й об'ємів скидання у водне середовище різних забруднюючих речовин мають не менше гідроекологічне значення, ніж об'єми викидів у гідрооб'єкти зворотних вод. На підставі даних Управління екології та природних ресурсів Черкаської

6 Шутак К. В. Техногенне забруднення поселенських гідроекосистем Черкаської області. The 11th International scientific and practical conference "Dynamics of the development of world science", July 8-10, 2020. Perfect Publishing, Vancouver, Canada. 2020. C. 479-489. 
облдержадміністрації, що наводяться для кожного гідрооб'єкта (річки або водосховища) окремо ${ }^{7}$, нами розраховано показники для басейнових груп поселенських гідроекосистем (табл. 3 ; 4).

Таблиця 3

\section{Обсяги скидів забруднюючих речовин у водні об'скти \\ Черкаської області (за басейновими групами \\ поселенських гідроекосистем), $\mathrm{m} /$ piк}

\begin{tabular}{|l|c|c|c|c|}
\hline \multirow{2}{*}{$\begin{array}{c}\text { Басейнова група } \\
\text { поселенських } \\
\text { гідроекосистем }\end{array}$} & 2016 & 2017 & 2018 & $\begin{array}{c}\text { Приріст у 2018 p. } \\
\text { проти 2016 p. }\end{array}$ \\
\cline { 2 - 5 } Дніпро & 1798,37 & 1527,01 & 2953 & 1154,63 \\
\hline Ятрань & 885,77 & $?$ & 2442 & 1556,23 \\
\hline Тясмин & 414,95 & 362,86 & 1712 & 1297,05 \\
\hline Гнилий Тікич & 371,48 & 255,66 & 940 & 568,52 \\
\hline Південний Буг & 34,97 & 40,29 & 95 & 60,03 \\
\hline Рось & 3,13 & 5,08 & 25 & 21,87 \\
\hline Гірський Тікич & 32,12 & 39,07 & 20 & $-12,12$ \\
\hline
\end{tabular}

Таблиця 4

\section{Об'єми скидання забруднюючих речовин у водні об'єкти Черкаської області (за басейновими групами поселенських гідроекосистем), млн м $^{38}$}

\begin{tabular}{|l|c|c|c|c|}
\hline \multirow{2}{*}{$\begin{array}{c}\text { Басейнова група } \\
\text { поселенських } \\
\text { гідроекосистем }\end{array}$} & 2016 & 2017 & 2018 & $\begin{array}{c}\text { Приріст у 2018 p. } \\
\text { проти 2016 p. }\end{array}$ \\
\cline { 2 - 5 } Дніпро & 2,4 & 2,23 & 2,57 & 0,17 \\
\hline Ятрань & 2,54 & $?$ & 2,56 & 0,02 \\
\hline Тясмин & 1,62 & 1,36 & 1,27 & $-0,35$ \\
\hline Гнилий Тікич & 0,53 & 0,59 & 0,6 & 0,07 \\
\hline Південний Буг & 0,11 & 0,13 & 0,12 & 0,01 \\
\hline Рось & 0,02 & 0,03 & 0,04 & 0,02 \\
\hline Гірський Тікич & 0,1 & 0,11 & 0,01 & $-0,09$ \\
\hline
\end{tabular}

Для встановлення закономірностей щодо динаміки зростання забруднень гідрооб'єктів Черкаської області ми оперуємо даними,

\footnotetext{
${ }^{7}$ Регіональна доповідь про стан навколишнього природного середовища в Черкаській області у 2018 році. Черкаси, 2019. 240 с.

8 Шутак К. В. Техногенне забруднення поселенських гідроекосистем Черкаської області. The 11th International scientific and practical conference "Dynamics of the development of world science", July 8-10, 2020. Perfect Publishing, Vancouver, Canada. 2020. C. 479-489. 
починаючи від 2016 р., позаяк саме вони є найбільш повними, а отже найпридатнішими для порівняння як різночасових показників для однієї басейнової групи поселенських гідроекосистем, так і показників одного року для різних груп.

За показниками обсягів скидів і об'ємів скидання речовинзабруднювачів водних об'єктів перше місце посідає дніпровська басейнова група поселенських гідроекосистем; найбільша частка викидів, так само як і в наведеному вище випадку зі скиданням зворотних вод, припадає на підприємства Черкас і Золотоноші. Варто наголосити, що обсяги скидів із часом виразно збільшуються, що загострює не лише гідроекологічні, а й медико-соціальні проблеми. Так само високим показником забрудненості водних об'єктів та приросту забруднень у 2018 р., як порівняти з 2016 р., відзначається ятранська басейнова група поселенських гідроекосистем (головним чином через викиди уманського міського водоканалу). Виявлені нами закономірності притаманні й більшості інших басейнових груп - річок Тясмин, Гнилий Тікич, Південний Буг, Рось. Зазначимо, що за показниками приросту обсягів скидів ятранська й тясминська групи навіть випереджають дніпровську (табл. 3). Винятки із загального правила становлять басейнові групи поселенських гідроекосистем Гірського Тікича та щодо об'ємів скидання - Тясмина, де обсяги забруднень у 2018 p. порівняно з 2016 р. навіть зменшилися, що може бути зумовлено або нерівномірністю функціонування об'єктів малої гідроенергетики, або браком чи неповнотою достовірних даних.

Для отримання повнішого уявлення про забруднення поверхневих вод Черкащини доцільне також проведення аналізу даних щодо об'ємів скидання та обсягів скидів у розрізі екістичних груп поселенських гідроекосистем. Ми взяли для вивчення 12 найбільш значущих таких систем (центрами яких є, як правило, міста з підприємствами), зіставили згадані вище показники щодо них і порівняли дані за 2016 і 2018 pp. (табл. 5).

3 таблиці видно, що найбільший рівень забруднення станом на 2018 р. мають гідрооб'єкти уманської екістичної групи поселенських гідроекосистем. Саме вона характеризується найбільшими показниками приросту обсягів скидів, що й визначило випередження нею черкаської групи, яка мала найвищі в області показники у 2016 р. Відзначимо також різкий стрибок у значеннях цього ж параметра для смілянської групи, хоча за об'ємами скидання забруднюючих речовин ситуація в межах останньої за два роки навіть поліпшилася (див. табл. 5). 
Об'єми скидання та обсяги скидів забруднюючих речовин у водні об'скти Черкаської області в розрізі найбільших екістичних груп поселенських гідроекосистем9

\begin{tabular}{|l|c|c|c|c|c|c|}
\hline \multirow{2}{*}{$\begin{array}{c}\text { Екістична група } \\
\begin{array}{c}\text { поселенських } \\
\text { гідроекосистем }\end{array}\end{array}$} & \multicolumn{2}{|c|}{ Об’еми скидання $\left(\right.$ млн м $\left.^{3}\right)$} & \multicolumn{3}{|c|}{ Обсяги скидів $(\mathrm{m} /$ рік $)$} \\
\cline { 2 - 8 } & 2016 & $\begin{array}{c}\text { Приріст у } \\
2018 \text { р. проти } \\
2016 \text { р. }\end{array}$ & 2016 & 2018 & $\begin{array}{c}\text { Приріст у } \\
2018 \text { р. проти } \\
2016 \text { р. }\end{array}$ \\
\hline Уманська & 2,54 & 2,57 & 0,03 & 885,77 & 2442 & 1556,23 \\
\hline Смілянська & 1,43 & 1,12 & $-0,31$ & 348,72 & 1539 & 1190,28 \\
\hline Черкаська & 1,54 & 1,73 & 0,19 & 1205,9 & 1501 & 295,1 \\
\hline Золотоніська & 0,79 & 0,76 & $-0,03$ & 557,34 & 1366 & 808,66 \\
\hline Ватутінська & 0,53 & 0,6 & 0,07 & 371,48 & 940 & 568,52 \\
\hline Чигиринська & 0,11 & 0,11 & 0 & 44,58 & 121 & 76,42 \\
\hline Христинівська & 0,11 & 0,12 & 0,01 & 34,97 & 95 & 60,03 \\
\hline Чорнобаївська & 0,06 & 0,07 & 0,01 & 35,13 & 86 & 50,87 \\
\hline Кам'янська & 0,78 & 0,04 & $-0,74$ & 21,66 & 52 & 30,34 \\
\hline Тальнівська & 0,09 & $0,1 *$ & 0,01 & 26 & $32,01 *$ & 6,01 \\
\hline $\begin{array}{l}\text { Корсунь- } \\
\text { Шевченківська }\end{array}$ & 0,02 & 0,04 & 0,02 & 3,13 & 25 & 21,87 \\
\hline Жашківська & 0,01 & 0,01 & 0 & 6,09 & 20 & 13,91 \\
\hline
\end{tabular}

*дані за 2017 p.

Обчислені дані щодо забруднення водних об'єктів шкідливими речовинами для екістичних груп поселенських гідроекосистем добре узгоджуються з наведеними вище показниками забруднення зворотними водами підприємств і виробництв. Більшість полютантів припадає на гідрооб'єкти уманської, смілянської, черкаської, золотоніської та ватутінської екістичних груп, де розташована переважна частина великих промислових підприємств області.

Через відсутність чіткої кореляції між показниками об'ємів скидання та обсягів скидів забруднюючих речовин ми визнаємо за доцільне розробити узагальнений показник, що досить повно міг би схарактеризувати екологічний стан поселенських гідроекосистем. Помножуючи показники об'ємів скидання на значення обсягів скидів, ми отримуємо узагальнений показник забруднення гідрооб'єктів цієї групи поселенських гідроекосистем, виражений у тоннах на мільйон кубометрів за рік $\left(m: M^{3} / p i \kappa\right)$. Результати відповідних обчислень для кожної групи поселенських гідроекосистем наведено в табл. 6 i 7.

9 Шутак К. В. Техногенне забруднення поселенських гідроекосистем Черкаської області. The 11th International scientific and practical conference "Dynamics of the development of world science", July 8-10, 2020. Perfect Publishing, Vancouver, Canada. 2020. C. 479-489. 
Також ми вважаємо за потрібне проведення бальної оцінки забруднення водних об'єктів за групами поселенських гідроекосистем (у тому числі абсолютних показників і приросту значень) та здійснення просторового аналізу забрудненості 3 виділенням кластерів, що включають території з близькими значеннями узагальнених показників забруднення. Найвищий бал (5) отримують групи 3 показниками понад $5000 \mathrm{~T} \cdot$ млн $\mathrm{m}^{3} /$ рік, 4 бали - 1000-5000 т $\cdot$ млн $\mathrm{m}^{3} /$ рік, 3 бали $100-1000 \mathrm{~T} \cdot$ млн $\mathrm{m}^{3} /$ рік, 2 бали $-1-100 \mathrm{~T} \cdot$ млн м³/рік, 1 бал - менше ніж $1 \mathrm{~T} \cdot$ млн $\mathrm{M}^{3} /$ рік.

Таблиця 6

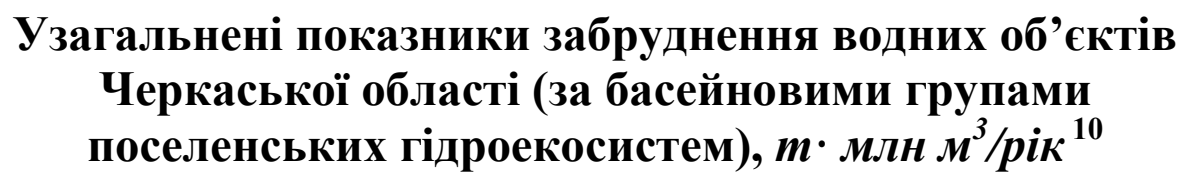

\begin{tabular}{|l|c|c|c|c|}
\hline \multirow{2}{*}{$\begin{array}{c}\text { Басейнова група } \\
\text { поселенських } \\
\text { гідроекосистем }\end{array}$} & 2016 & 2017 & 2018 & $\begin{array}{c}\text { Приріст у } \\
2018 \text { р. проти } \\
2016 \text { р. }\end{array}$ \\
\cline { 1 - 4 } Дніпро & 4316,09 & 3405,23 & 7589,21 & 3272,31 \\
\hline Ятрань & 2276,43 & $?$ & 6251,52 & 3975,09 \\
\hline Тясмин & 672,22 & 493,49 & 2174,24 & 1502,02 \\
\hline Гнилий Тікич & 196,88 & 150,84 & 564 & 367,12 \\
\hline Південний Буг & 3,85 & 5,24 & 11,4 & 7,55 \\
\hline Рось & 0,06 & 0,15 & 1 & 0,02 \\
\hline Гірський Тікич & 3,21 & 4,3 & 0,2 & $-3,01$ \\
\hline
\end{tabular}

У формуванні кластерів необхідно врахувати також бальну оцінку приросту забруднень. Зокрема, п'ятьом балам відповідають показники понад $3000 \mathrm{~T} \cdot \mathrm{млн} \mathrm{m}^{3} /$ рік, чотирьом - від 1000 до 3000, трьом 100-1000, двом - від 0 до $100 \mathrm{~T} \cdot$ млн м³/рік, одному - менш ніж 0 т $\cdot$ млн $\mathrm{m}^{3} /$ рік (від’ємні значення).

Таким чином, у розрізі басейнових груп поселенських гідроекосистем, 3 урахуванням абсолютного значення й приросту показників, по 10 балів одержують дніпровська та ятранська групи, 8 - тясминська, 6 басейнова група поселенських гідроекосистем Гнилого Тікича, по $4-$ Південного Бугу та Росі, 2 бали - група Гірського Тікича (рис. 4). Щодо екістичних груп, то уманська отримує 10 балів, смілянська - 8, черкаська й золотоніська - по 7, ватутінська - 6, чигиринська, христинівська, чорнобаївська, тальнівська та корсунь-шевченківська по 4, жашківська та кам'янська - по 3 (рис. 5).

10 Шутак К. В. Техногенне забруднення поселенських гідроекосистем Черкаської області. The 11th International scientific and practical conference "Dynamics of the development of world science", July 8-10, 2020. Perfect Publishing, Vancouver, Canada. 2020. C. 479-489. 


\section{Узагальнені показники забруднення водних об'єктів Черкаської області (за екістичними групами поселенських гідроекосистем), $\boldsymbol{m} \cdot$ млн $\boldsymbol{м}^{3} / \mathbf{p i \kappa}$}

\begin{tabular}{|l|c|c|c|}
\hline \multirow{2}{*}{$\begin{array}{c}\text { Екістична група } \\
\text { поселенських } \\
\text { гідроекосистем }\end{array}$} & 2016 & 2018 & \multirow{2}{|c|}{$\begin{array}{c}\text { Приріст у 2018 p. } \\
\text { проти 2016 p. }\end{array}$} \\
\cline { 2 - 3 } & 2249,86 & 6275,94 & 4026,08 \\
\hline Уманська & 1857,09 & 2596,73 & 739,64 \\
\hline Черкаська & 498,67 & 1723,68 & 1225,01 \\
\hline Смілянська & 440,3 & 1038,16 & 597,86 \\
\hline Золотоніська & 196,88 & 564 & 367,12 \\
\hline Ватутінська & 4,9 & 13,31 & 8,41 \\
\hline Чигиринська & 3,85 & 11,4 & 7,55 \\
\hline Христинівська & 2,11 & 6,02 & 3,91 \\
\hline Чорнобаївська & 2,34 & 3,2 & 0,86 \\
\hline Тальнівська & 16,89 & 2,08 & $-14,81$ \\
\hline Кам'янська & 0,06 & 1 & 0,94 \\
\hline Корсунь-Шевченківська & 0,06 & 0,2 & 0,14 \\
\hline Жашківська & & & \\
\hline
\end{tabular}

Відзначимо, що суміжні екістичні групи поселенських гідроекосистем можуть становити єдиний кластер у разі належності їх територій до одного річкового басейну (принаймні середньої річки). Тому, через недостатню інформацію про гідроекологічний стан водотоків драбівської, маньківської, монастирищенської й деяких інших екістичних груп, ми допускаємо поширення на них даних для груп золотоніської, тальнівської та христинівської відповідно. Такий підхід ми втілюємо в картосхемі (див. рис. 5).

Варто зауважити, що окреслена кластеризація не являє собою районування, тому що, по-перше, просторові утворення $з$ однаковими бальними характеристиками не всюди $є$ суміжними, а по-друге, враховані критерії й показники дають недостатньо повну картину гідроекологічної ситуації для проведення районування. Зокрема, виділені кластери слабко віддзеркалюють дію біотичного фактора, не враховують екологічного стану підземних вод тощо.

3 географічного погляду відображена в картосхемах (див. рис. 4 і 5) просторова інформація $\epsilon$ суспільно-географічною, оскільки вона відображає закономірності, пов'язані виключно 3 виробництвом, i відмінності в значеннях узагальненого показника забруднення не корелюють із дією природних факторів. 


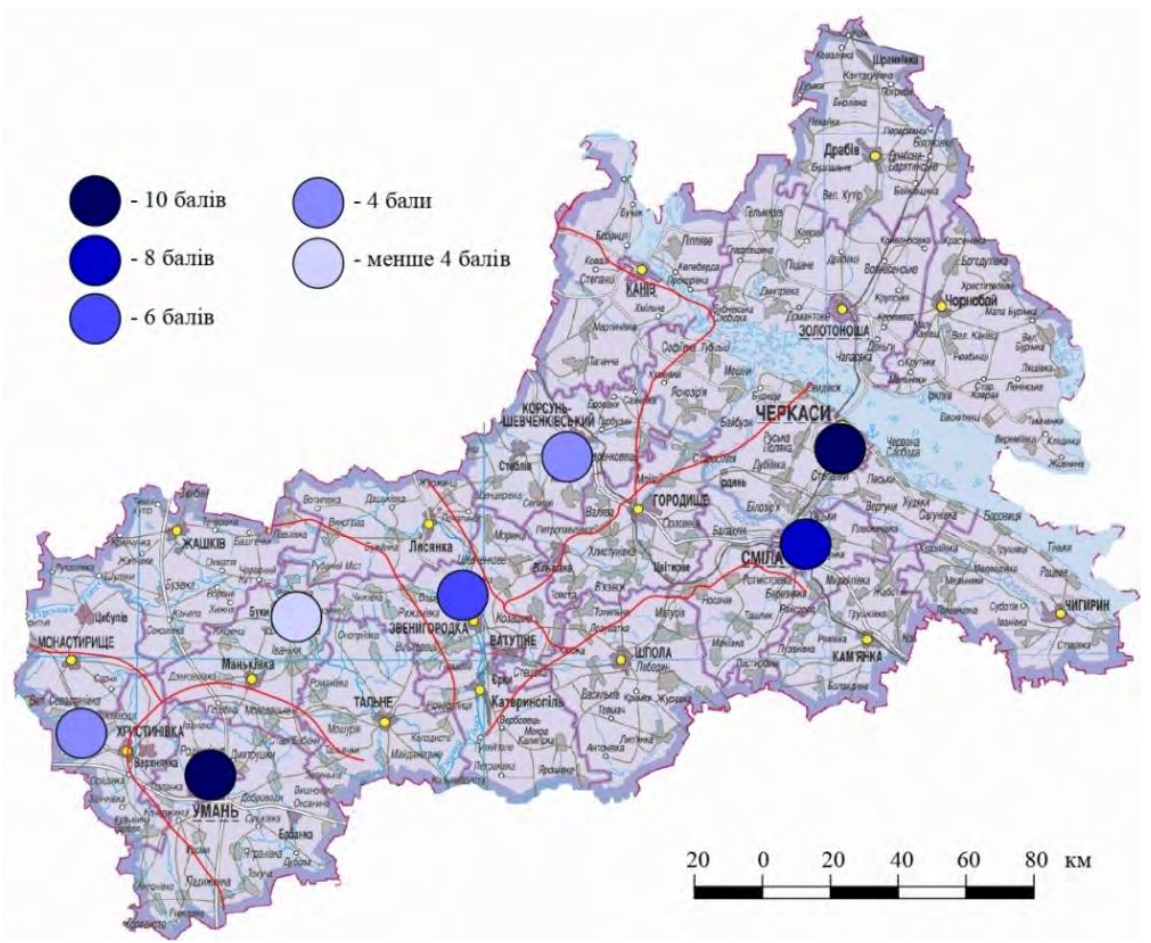

Рис. 4. Бальна характеристика забруднення водних об'єктів за басейновими групами поселенських гідроекосистем Черкаської області

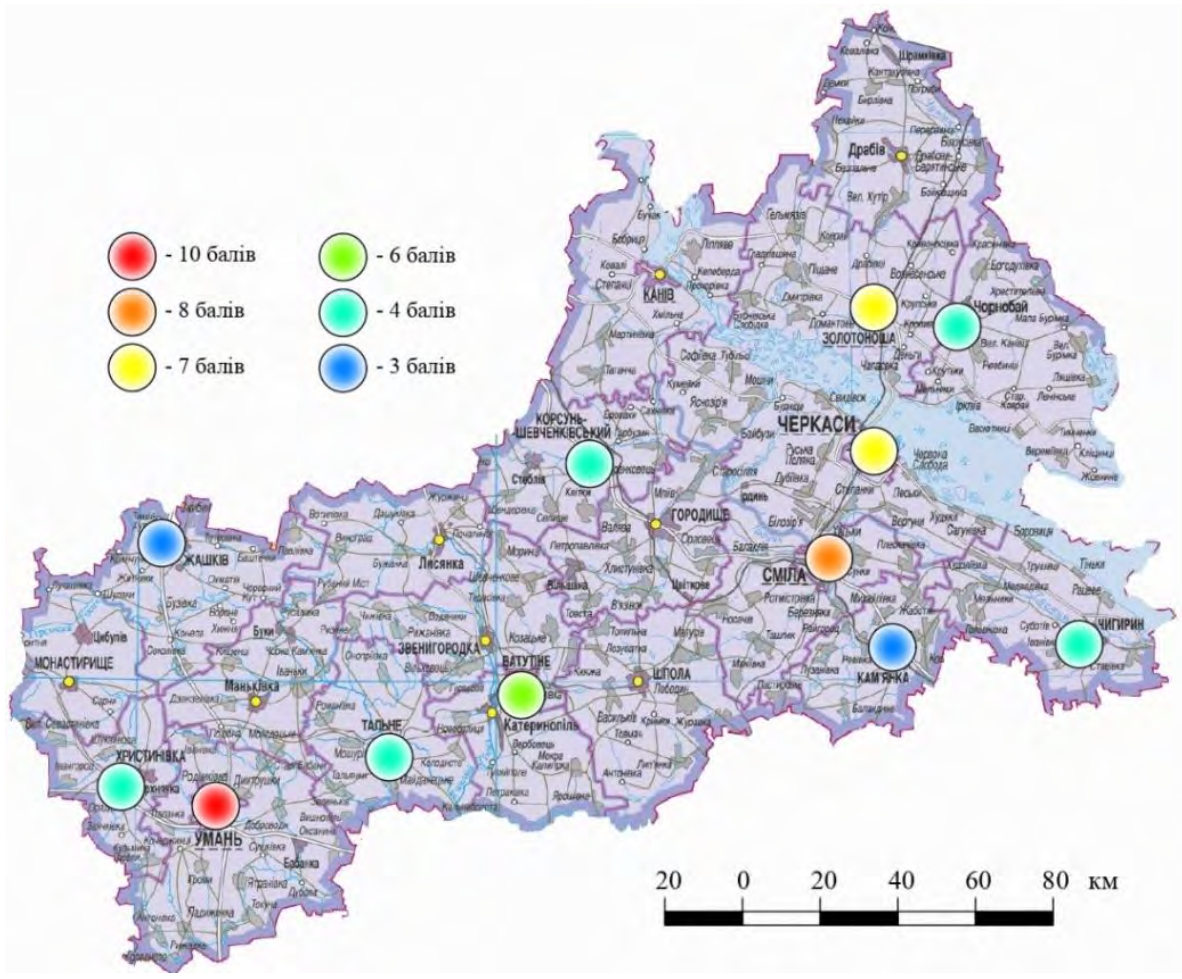

Рис 5. Бальна характеристика забруднення водних об'сктів за екістичними групами поселенських гідроекосистем Черкаської області 


\section{ВИСНОВКИ}

Забрудненість водних об'єктів Черкаської області схарактеризовано в розрізі груп поселенських гідроекосистем. Зазначені просторові утворення можуть виділятися за басейновою ознакою, тоді вони охоплюють території водозборів великих і середніх (понад 100 км завдовжки) річок включно 3 усіма малими річками й струмками (басейнові групи поселенських гідроекосистем). Також можливе виокремлення груп поселенських гідроекосистем навколо досить великого населеного пункту (міста або селища міського типу), такі групи ми називаємо екістичними. Займані ними площі можуть збігатися 3 територіями адміністративних районів. Обидва згадані підходи до групування поселенських гідроекосистем є конструктивними 3 погляду можливості одержання об'єктивної інформації про екологічний стан водного середовища в регіоні.

В аспекті гідрохімічної характеристики груп поселенських гідроекосистем найбільшу увагу було приділено скиданню зворотних вод і забруднюючих речовин - параметрам, які, на наш погляд, створюють найбільш повне уявлення про відхилення екологічного стану водних об'єктів від доброго.

Обчислення різних показників у розрізі басейнових груп засвідчили, що найбільше забруднення гідрооб'єктів властиве дніпровській, ятранській і тясминській групам поселенських гідроекосистем. У цьому проявляється виразна закономірність, яка верифікується за допомогою даних, отриманих для екістичних груп поселенських гідроекосистем. Вони засвідчують, що найбільшими показниками забруднення вирізняються гідрооб'єкти черкаської, уманської та смілянської груп, центрами яких є найважливіші промислові міста Черкаської області.

Специфічні гідроекологічні проблеми притаманні підземним водам. Позаяк використання їх як джерел водопостачання властиве переважно сільській місцевості, головними чинниками погіршення екологічного стану є не промислові, а господарсько-побутові стоки.

\section{АНОТАЦІЯ}

Висвітлено суть поняття «поселенська гідроекосистема». Окреслено структуру найбільших поселенських гідроекосистем Черкаської області. Сформульовано басейновий й екістичний підходи до групування поселенських гідроекосистем. Розраховано показники об'ємів скидів зворотних стічних вод і забруднюючих речовин у водні об'єкти Черкащини в розрізі груп поселенських гідроекосистем. Обгрунтовано зміст узагальненого показника забруднення водного середовища. Обчислено значення узагальнених показників забруднення за основними 
групами поселенських гідроекосистем. Проведено кластеризацію груп поселенських гідроекосистем за ознакою забруднення водних об’єктів.

\section{ЛІТЕРАТУРА}

1. Кисельов Ю. О., Шутак К. В. До проблеми формування наукових засад урбогідроекології. Молодий вчений. 2019. № 7 (71). С. 10-13.

2. Кисельов Ю. О., Шутак К. В. Основні підходи до групування поселенських гідроекосистем Черкаської області. SWorld Journal. Травень, 2020. Вип. 4. Ч. 1. С. 98-101.

3. Екологічний паспорт Черкаської області на 2017 рік. Черкаси, 2018. $261 \mathrm{c}$.

4. Шутак К. В. Техногенне забруднення поселенських гідроекосистем Черкаської області. The 11th International scientific and practical conference "Dynamics of the development of world science", July 8-10, 2020. Perfect Publishing, Vancouver, Canada. 2020. C. 479-489.

5. Регіональна доповідь про стан навколишнього природного середовища в Черкаській області у 2018 році. Черкаси, 2019. 240 с.

\section{Information about authors: Kyselov Yu. O.,}

Doctor of Geographical Sciences, Professor, Head of the Department of Geodesy, Cartography and Cadastre

Uman National University of Horticulture 1, Instytutska str., Uman, Cherkasy region, 20300, Ukraine

Shutak K. V., Postgraduate Student at the Department of Ecology and Life Safety Uman National University of Horticulture 1, Instytutska str., Uman, Cherkasy region, 20300, Ukraine 